\title{
Comparison of nitrogen fixation rates determined with different methods: a study in the Baltic Proper
}

\author{
Norbert Wasmund ${ }^{*}$, Günther Nausch, Bernd Schneider, Klaus Nagel, Maren Voss
}

Baltic Sea Research Institute Warnemünde, Seestrasse 15, 18119 Rostock-Warnemünde, Germany

\begin{abstract}
Nitrogen fixation rates were determined at approximately monthly intervals during spring/summer 2001 in the eastern Gotland Sea by means of the ${ }^{15} \mathrm{~N}_{2}$ method. Additionally, a comprehensive set of variables were measured in order to apply 3 different budget approaches for the determination of integrated nitrogen fixation: (1) the nutrient concept based on excess $\mathrm{PO}_{4}$ owing to the low DIN/ $\mathrm{PO}_{4}$ ratios (6.8) in the winter surface water, (2) the $\mathrm{CO}_{2}$ concept using a combined carbon/nitrogen mass balance and (3) the biomass concept based on the increase in total nitrogen during the cyanobacteria bloom. For the spring season (March to May) the budget approaches gave rise to postulating an additional nitrogen input of about 100 to $200 \mathrm{mmol} \mathrm{m}^{-2}$. However, this was not attributed to nitrogen fixation because ${ }^{15} \mathrm{~N}_{2}$ rate measurements from several years did not show any significant nitrogen fixation during spring. Rate measurements integrated from May to August yielded a nitrogen fixation of $138 \mathrm{mmol} \mathrm{m}^{-2}$, which was consistent with the estimate based on the biomass concept. The $\mathrm{CO}_{2}$ concept resulted in a nitrogen input of $268 \mathrm{mmol} \mathrm{m}^{-2}$ from May to August. The nutrient concept was questionable because the excess $\mathrm{PO}_{4}$ was consumed during spring and not transferred to the summer bloom. High PON/POP ratios in summer indicated that $\mathrm{PO}_{4}$ release from particulate organic matter provided some of the $\mathrm{PO}_{4}$ necessary for the primary production based on nitrogen fixation. The estimates obtained from the rate measurements and from the $\mathrm{CO}_{2}$ concept are considered to represent the lower and upper limit for the nitrogen fixation in the Baltic Proper and correspond to a total nitrogen input of 434000 and $792000 \mathrm{t} \mathrm{yr}^{-1}$ respectively.
\end{abstract}

KEY WORDS: Nitrogen fixation $\cdot$ Cyanobacteria bloom $\cdot$ Nutrient $\cdot$ Redfield ratio $\cdot$ Baltic Sea Resale or republication not permitted without written consent of the publisher

\section{INTRODUCTION}

The Baltic Sea is a shallow intracontinental sea with an area of about $400000 \mathrm{~km}^{2}$, structured by large gulfs and deep central basins. Due to high nutrient input from the large drainage area $\left(1729000 \mathrm{~km}^{2}\right.$, Bergström \& Carlsson 1994) and sluggish water exchange with the North Sea, eutrophication is a major environmental issue for the Baltic Sea. Additionally, blooms of cyanobacteria, mainly Nodularia spumigena and Aphanizomenon sp., contribute to the nutrient input by their ability for nitrogen fixation, an enzymatic process that converts molecular $\mathrm{N}_{2}$ into organic nitrogen (cf. Sellner 1997).

Early estimates of nitrogen fixation by Melvasalo et al. (1983), Rönner (1985) and Leppänen et al. (1988) gave annual rates of 10000 to $130000 \mathrm{t} \mathrm{N}$ in the Baltic Proper and the Gulf of Finland. However, long-term measurements by Hübel \& Hübel (1995) indicated that the annual rates may vary by a factor of 10 . Most of the early investigations concentrated on the summer period when massive cyanobacteria blooms occur and facilitate sampling and enrichment by plankton net tows. Wasmund et al. (2001b) extended the measurements to the vegetation period (February to November) and included coccoid cyanobacteria as well as night measurements. This methodological improvement resulted in an increased mean annual nitrogen fixation (370000 t N) in 1997 to 1998 for the Baltic Proper. A shortcoming of their estimate is due to a gap in the data series in June when the bloom development starts. Even if not visible as surface blooms, the nitro- 
gen-fixing cyanobacteria are already present in the trophogenic layer in June (Hübel \& Hübel 1995, Ohlendieck et al. 2000). Hence, neglecting this period may lead to an underestimation of the annual nitrogen fixation.

The purpose of this study was to determine nitrogen fixation rates by the ${ }^{15} \mathrm{~N}$ method with an enhanced temporal resolution of about 1 mo for the period March to October. Since cyanobacteria colonies show a patchy distribution, integration of the rates over time and space involves uncertainties which can hardly be quantified. Therefore, we also consider different integrating approaches to determine the annual nitrogen fixation. These are based on (1) the excess $\mathrm{PO}_{4}$ available for nitrogen fixation after the spring bloom ('nutrient concept', Rahm et al. 2000), (2) a combined surface water carbon/nitrogen budget (' $\mathrm{CO}_{2}$ concept', Schneider et al. 2003) and (3) the temporal increase of total nitrogen compounds in the euphotic zone ('biomass concept', Larsson et al. 2001). The results of these approaches are compared and their applicability is discussed.

\section{MATERIALS AND METHODS}

Investigation area. The investigations were conducted in the eastern Gotland Sea $\left(44390 \mathrm{~km}^{2}\right)$, which is the central deep area of the Baltic Proper $\left(211069 \mathrm{~km}^{2}\right)$. The Baltic Proper stretches from the entrances to the Gulfs of Bothnia, Finland and Riga in the north-east to the Darss Sill in the south-west (Fig. 1) and is the area with the highest cyanobacteria concentration in the Baltic Sea (cf. Kahru et al. 1994). The open Baltic Proper is permanently stratified by a halocline located between 60 and $80 \mathrm{~m}$ in the eastern Gotland Sea. During spring a thermocline develops and stabilises in summer. It separates the upper mixed layer from the intermediate water and hampers the diapycnal exchange. The phytoplankton bloom starts as soon as the upper mixed layer becomes shallower than the euphotic zone (Wasmund et al. 1998). The lower border of the intermediate water is marked by the halocline. Our investigations were performed at the Gotland Deep Stn (249 m) BMP J1 (57²19.20' N, $20^{\circ} 03.00^{\prime} \mathrm{E}$ ) in the centre of the eastern Gotland Sea. The hydrographic-hydrochemical conditions in 2001 are described in detail by Nausch et al. (2002).

Sampling. During 6 cruises a comprehensive measurement programme was performed at the central Stn BMP J1, each lasting 3 to $6 \mathrm{~d}$, between 28 March and 4 September 2001 (see Table 1). Additional investigations with a reduced set of variables were carried out on 27 June and 6 October 2001. Temperature, salinity, oxygen and fluorescence were recorded using a CTD

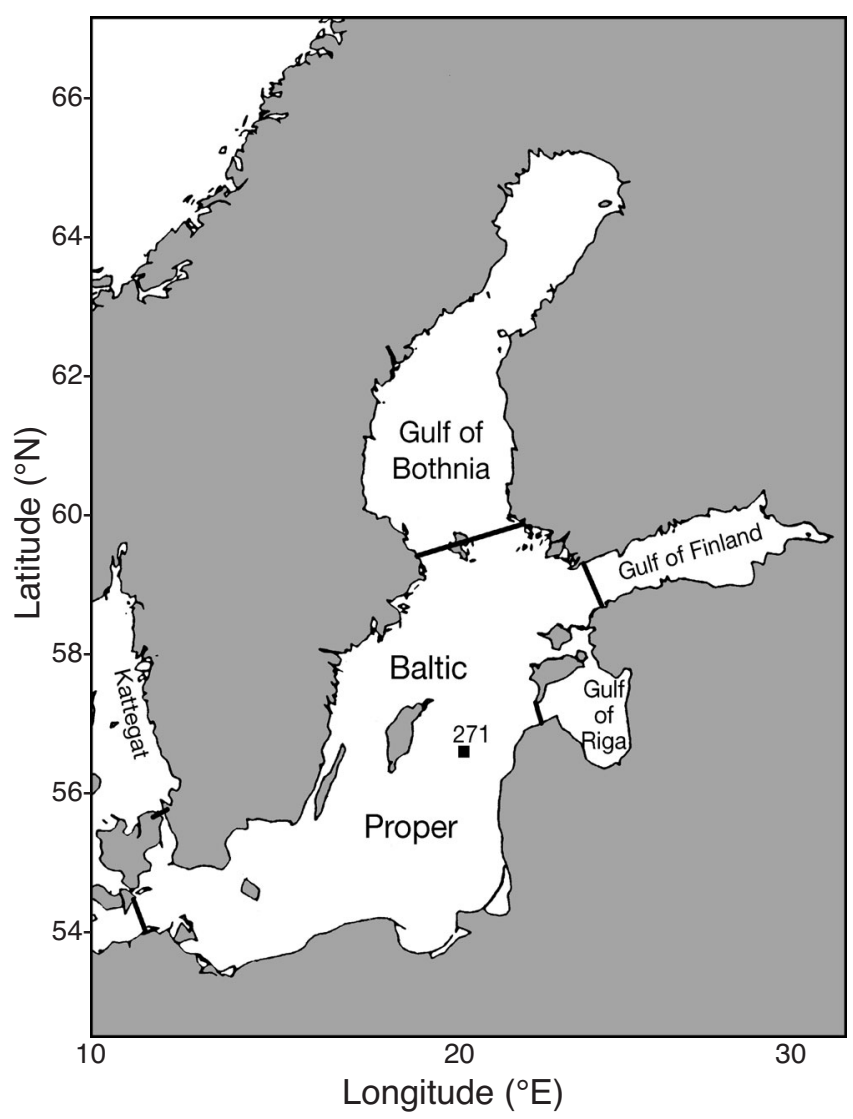

Fig. 1. Investigation area with Stn BMP J1 and borders of the Baltic Proper indicated

Seabird 911 with an oxygen sensor and a 2-channel Haardt fluorometer combined with a HydroBios rosette sampler containing twelve 51 bottles. Water samples for chemical analysis were taken at 1, 5, 10, 15, 20, 30, 40,50 and $60 \mathrm{~m}$ depths. A higher sampling depth resolution $(1,2.5,5,7.5,10,15$ and occasionally $20 \mathrm{~m})$ was applied for the determination of nitrogen fixation rates, chlorophyll $a$ and phytoplankton biomass. Depth profiles for the light intensity were measured with a LICOR Data Logger LI-1000 equipped with a spherical underwater light sensor.

Rate measurements. The ${ }^{15} \mathrm{~N}$ tracer technique (Montoya et al. 1996) was applied to determine nitrogen fixation rates. Two samples from each standard depth were filled bubble-free into $250 \mathrm{ml}$ incubation bottles and spiked with $0.5 \mathrm{ml}{ }^{15} \mathrm{~N}_{2}\left(99 \%{ }^{15} \mathrm{~N}_{2}\right.$, Campro Scientific) via a gas-tight septum. The bottles were carefully shaken in order to achieve isotopic equilibrium between the gaseous ${ }^{15} \mathrm{~N}_{2}$ and natural dissolved $\mathrm{N}_{2}$. The samples were exposed to in situ light intensities by placing the bottles in plastic tubes covered with a screen for attenuation of the incident solar radiation. According to the measured radiation profiles, samples from $2.5,5,7.5,10$ and $15 \mathrm{~m}$ were in most of the exper- 
iments exposed to reduced light intensities of $30 \%$, $15 \%, 7 \%, 4 \%$ and total darkness respectively. For the surface sample (approximately $1 \mathrm{~m}$ ) both 100\% and $50 \%$ light intensities were applied. In most cases the $15 \mathrm{~m}$ sample originated from below the thermocline. The samples were incubated at an unshaded place on deck and cooled with surface water. After $2 \mathrm{~h}$ of incubation, the samples were filtered onto precombusted Whatman GF/F filters and stored frozen until analysis with a continuous-flow isotope ratio mass spectrometer (Finnigan, Delta $\mathrm{S}$ ). Pure $\mathrm{N}_{2}$ calibrated against International Atomic Energy Agency standards (N1, N2, N3) was used as reference gas. The calculation of nitrogen fixation rates from the mass spectrometric ${ }^{15} \mathrm{~N}$ data was performed according to Montoya et al. (1996).

In order to integrate nitrogen fixation over the depth of the euphotic zone ( $1 \%$ light intensity, see Table 1 ), the rates at the individual sampling depths were interpolated linearly. In order to account for the daily cycle (Wasmund et al. 2001b), nitrogen fixation rates were obtained from 3 incubations at different times each day. Measurements in the morning (08:00 to 10:00 h), in the afternoon (14:00 to $16: 00 \mathrm{~h})$ and during the night (22:00 to $24: 00 \mathrm{~h})$ were considered to represent the time intervals from sunrise to noon, noon to sunset and for the night hours. By this strategy (6 depths in duplicate, 3 incubations), each daily value was based on 36 samples.

Analytical methods. Samples for the analysis of particulate organic carbon (POC) and particulate organic nitrogen (PON) were filtered on Whatman GF/F filters, stored at $-20^{\circ} \mathrm{C}$ and analysed according to standard procedures using a CHN Analyser (model Vario el, Elementar Analysensysteme) (Ehrhardt \& Koeve 1999). The filtrate was sealed in ampoules, stored at $-20^{\circ} \mathrm{C}$ and analysed for dissolved organic carbon (DOC) and dissolved nitrogen (DN) with a Shimadzu TOC5000 TOC analyser (Shimadzu) coupled to a Skalar ND10 total nitrogen detector (Skalar Analytical). The determination was based on high temperature catalytic oxidation of the dissolved organic material to $\mathrm{CO}_{2}$ and $\mathrm{NO}$ and subsequent quantification of $\mathrm{CO}_{2}$ by an infrared spectrometry and of $\mathrm{NO}$ by a chemiluminescent detector (Cauwet 1999). The quality of the analytical procedure was regularly checked by the use of reference material (Sharp 2002). Dissolved organic nitrogen (DON) was determined from the difference between dissolved nitrogen and dissolved inorganic nitrogen (DIN).

Nutrient concentrations (phosphate, nitrate, nitrite, ammonium) were determined by standard photometric methods described by Rohde \& Nehring (1979) and Grasshoff et al. (1983). Samples for total and dissolved phosphorus were oxidised with an alkaline peroxodisulfate solution (Grasshoff et al. 1983) and subsequent photometric determination of $\mathrm{PO}_{4}$. Dissolved organic phosphorus (DOP) was obtained from the difference between dissolved phosphorus and inorganic $\mathrm{PO}_{4}$, whereas particulate organic phosphorus (POP) is the difference between total phosphorus and dissolved phosphorus.

For the determination of chlorophyll $a$ and phaeopigment $a_{1} 250$ to $500 \mathrm{ml}$ of the water sample were filtered using Whatman GF/F filters. After storage at $-20^{\circ} \mathrm{C}$, the filters were extracted with $90 \%$ acetone according to a slightly modified procedure suggested by HELCOM (1988). The chlorophyll $a$ and phaeopigment $a$ fluorescence was determined with a TURNER fluorometer (10-AU-005) and the corresponding concentrations were calculated according to Jeffrey \& Welschmeyer (1997).

The preparation of integrated samples from 1, 2.5, 5, 7.5 and $10 \mathrm{~m}$ depth, preservation with acetic Lugol solution $\left(\mathrm{KI} / \mathrm{I}_{2}\right)$ and counting with an inverted microscope for the determination of the phytoplankton biomass in the upper mixed layer were performed according to the HELCOM (1988) guidelines.

\section{RESULTS}

\section{Nitrogen fixation rates}

The mean daily nitrogen fixation rates for each cruise are shown in Table 1 for the upper mixed layer and in Table 2 for the intermediate water. The sum of these rates, which refer to nitrogen fixation in the euphotic zone for each measurement period, are given in Fig. 2. In order to determine nitrogen fixation for the entire productive period, we assigned the start of the nitrogen fixation activity to 26 April 2001, when DIN fell below $0.1 \mathrm{mmol} \mathrm{m}^{-3}$ (Cruise report RV 'Argos' from 25 April to 28 April 2001, Swedish Meteorological and Hydrological Institute). Since no data were available for May, we used the mean of the fixation rates measured during May in 6 other years (Table 3). The smoothed seasonal nitrogen fixation curve (Fig. 2) was used for integrating the rates for the periods between the cruises (Table 4). The total nitrogen fixation for the main productive period May to August was $139 \mathrm{mmol}$ $\mathrm{m}^{-2}$. The contribution of the post-bloom period from August to October (9 $\mathrm{mmol} \mathrm{N} \mathrm{m}^{-2}$ ) was insignificant.

\section{Nutrient concept}

A simple approach to estimating the new production of organic carbon is based on the nutrient consumption during the productive period and the use of Redfield's POC/PON (6.625) and/or POC/POP ratios 
Table 1. Mean data from each cruise in upper mixed layer of Stn BMP J1. TN = total nitrogen

\begin{tabular}{|c|c|c|c|c|c|c|c|c|}
\hline & \multicolumn{8}{|c|}{ Sampling period (2001) - } \\
\hline & $28.3-30.3$ & $13.5-15.5$ & $9.6-14.6$ & 27.6 & $11.7-16.7$ & $2.8-5.8$ & $31.8-4.9$ & 6.10 \\
\hline No. of days for rate measurements & 0 & 0 & 1 & 1 & 3 & 2 & 2 & 1 \\
\hline Mean depth of thermocline (m) & no & 14.9 & 12.9 & nd & 11.7 & 14.7 & 18.2 & 25.0 \\
\hline Mean depth of euphotic zone (m) & nd & 20 & 24 & nd & 18 & 15 & 15 & 13 \\
\hline $\mathrm{DIN}\left(\mathrm{mmol} \mathrm{m}^{-3}\right)$ & 3.13 & 0.37 & 0.17 & nd & 0.40 & 0.34 & 0.24 & 1.73 \\
\hline $\mathrm{PO}_{4}(\mathrm{mmol} \mathrm{m}-3)$ & 0.46 & 0.10 & 0.03 & nd & 0.01 & 0.03 & 0.01 & 0.14 \\
\hline POC $\left(\mathrm{mmol} \mathrm{m}^{-3}\right)$ & 10.8 & 36.1 & 21.1 & nd & 43.2 & 18.1 & 20.7 & 8.2 \\
\hline PON $\left(\mathrm{mmol} \mathrm{m}^{-3}\right)$ & 1.5 & 3.6 & 2.7 & nd & 5.7 & 2.6 & 2.7 & 1.2 \\
\hline POP $\left(\mathrm{mmol} \mathrm{m}^{-3}\right)$ & 0.07 & 0.19 & 0.16 & nd & 0.16 & 0.17 & 0.18 & nd \\
\hline $\mathrm{DOC}\left(\mathrm{mmol} \mathrm{m}^{-3}\right)$ & 322 & 318 & 331 & nd & 413 & 358 & 364 & nd \\
\hline DON (mmol m$\left.{ }^{-3}\right)$ & 19.9 & 19.0 & $17.4^{\mathrm{a}}$ & nd & $19.8^{\mathrm{b}}$ & 21.4 & nd & nd \\
\hline $\mathrm{DOP}\left(\mathrm{mmol} \mathrm{m}^{-3}\right)$ & 0.24 & 0.24 & 0.23 & nd & 0.22 & 0.20 & 0.21 & nd \\
\hline $\mathrm{TN}\left(\mathrm{mmol} \mathrm{m}^{-3}\right)$ & 24.6 & 22.9 & 20.3 & nd & 25.8 & 24.4 & nd & nd \\
\hline Phytoplankton C (mmol mn & 4.10 & 10.01 & 13.06 & nd & 14.10 & 7.05 & 5.73 & 6.14 \\
\hline $\mathrm{Chl} \mathrm{a}\left(\mathrm{mg} \mathrm{m}^{-3}\right)$ & 1.60 & 1.92 & 1.47 & nd & 3.40 & 1.78 & 1.63 & 1.94 \\
\hline $\mathrm{POC} / \mathrm{PON}$ & 7.0 & 10.1 & 7.7 & nd & 7.6 & 6.9 & 7.7 & 6.8 \\
\hline $\mathrm{POC} / \mathrm{POP}$ & 161 & 195 & 132 & nd & 270 & 106 & 115 & nd \\
\hline PON/POP & 22.0 & 18.7 & 17.1 & nd & 35.4 & 15.5 & 15.0 & nd \\
\hline Nitrogen fixation $\left(\mathrm{mmol} \mathrm{N} \mathrm{m} \mathrm{m}^{-2} \mathrm{~d}^{-1}\right.$ ) & nd & $0.1^{\mathrm{c}}$ & 2.32 & 1.10 & 0.63 & 0.15 & 0.16 & 0.08 \\
\hline
\end{tabular}

${ }^{a}$ Mean from a station grid around Stn BMP J1; ${ }^{b}$ interpolated value; ${ }^{c}$ value based on long-term means, cf. Table 3

Table 2. Mean data from each cruise in the intermediate water of Stn BMP J1. TN = total nitrogen

\begin{tabular}{|c|c|c|c|c|c|c|c|c|}
\hline & \multirow[b]{2}{*}{$28.3-30.3$} & \multirow[b]{2}{*}{$13.5-15.5$} & \multicolumn{3}{|c|}{ Sampling period (2001) } & \multirow[b]{2}{*}{$2.8-5.8$} & \multirow[b]{2}{*}{$31.8-4.9$} & \multirow[b]{2}{*}{6.10} \\
\hline & & & $9.6-14.6$ & 27.6 & $11.7-16.7$ & & & \\
\hline $\mathrm{DIN}\left(\mathrm{mmol} \mathrm{m} \mathrm{m}^{-3}\right)$ & 3.92 & 0.27 & 0.31 & nd & 0.57 & 0.45 & 0.59 & nd \\
\hline $\mathrm{PO}_{4}\left(\mathrm{mmol} \mathrm{m}{ }^{-3}\right)$ & 0.52 & 0.14 & 0.15 & nd & 0.14 & 0.09 & 0.14 & nd \\
\hline $\mathrm{POC}\left(\mathrm{mmol} \mathrm{m}^{-3}\right)$ & 10.8 & 15.0 & 8.1 & nd & 19.6 & 11.3 & 18.8 & nd \\
\hline $\mathrm{PON}\left(\mathrm{mmol} \mathrm{m}^{-3}\right)$ & 1.5 & 1.7 & 1.1 & nd & 2.7 & 1.6 & 2.6 & nd \\
\hline POP $\left(\mathrm{mmol} \mathrm{m}^{-3}\right)$ & 0.03 & 0.09 & nd & nd & nd & 0.04 & nd & nd \\
\hline $\mathrm{DOC}\left(\mathrm{mmol} \mathrm{m}^{-3}\right)$ & 322 & 321 & 347 & nd & 363 & 336 & 352 & nd \\
\hline $\mathrm{DON}\left(\mathrm{mmol} \mathrm{m}^{-3}\right)$ & 19.9 & 20.0 & 17.1 & nd & $17.0^{\mathrm{a}}$ & 16.9 & nd & nd \\
\hline $\mathrm{DOP}\left(\mathrm{mmol} \mathrm{m}^{-3}\right)$ & 0.16 & 0.16 & nd & nd & nd & 0.27 & nd & nd \\
\hline $\mathrm{TN}\left(\mathrm{mmol} \mathrm{m}{ }^{-3}\right)$ & 25.4 & 22.0 & 18.5 & nd & 20.3 & 18.9 & nd & nd \\
\hline POC/PON & 7.0 & 8.7 & 7.7 & nd & 7.3 & 7.2 & 7.1 & nd \\
\hline POC/POP & 360 & 166 & nd & nd & nd & 323 & nd & nd \\
\hline PON/POP & 51.3 & 19.2 & nd & nd & nd & 45.1 & nd & nd \\
\hline Nitrogen fixation $\left(\mathrm{mmol} \mathrm{N} \mathrm{m} \mathrm{m}^{-2} \mathrm{~d}^{-1}\right)$ & nd & $0.06^{\mathrm{b}}$ & 1.37 & 0.25 & 0.16 & 0.00 & 0.00 & 0.00 \\
\hline
\end{tabular}

Table 3. Nitrogen fixation rates in May of different years, taken at Stn BMP J1 with the same method, considering a $20 \mathrm{~m}$ water column

\begin{tabular}{|lc|}
\hline Date & Nitrogen fixation $\left(\mathrm{mmol} \mathrm{N} \mathrm{m}^{-2} \mathrm{~d}^{-1}\right)$ \\
\hline 17.5 .1995 & 0.065 \\
$12 .-19.5 .1998$ & 0.055 \\
14.5 .1999 & 0.260 \\
12.5 .2000 & 0.240 \\
8.5.2002 & 0.164 \\
4.5 .2004 & 0.149 \\
Mean value & $\mathbf{0 . 1 5 6}$ \\
\hline
\end{tabular}

(106). Winter nutrient concentrations in the Baltic Proper surface water are characterised by a mean DIN/PO $\mathrm{PO}_{4}$ ratio of 7.9 (Matthäus et al. 2001) and exhibit a distinct $\mathrm{PO}_{4}$ excess (DIN deficit) with regard to the demand by phytoplankton according to Redfield et al. (1963). Hence, DIN is considered to limit the spring bloom in the Baltic Proper and may be used to calculate the new production during this early stage of the phytoplankton succession. However, new production continues due to the availability of excess $\mathrm{PO}_{4}$. The deficient nitrogen can be supplied by nitrogen fixation, which is consequently limited by 


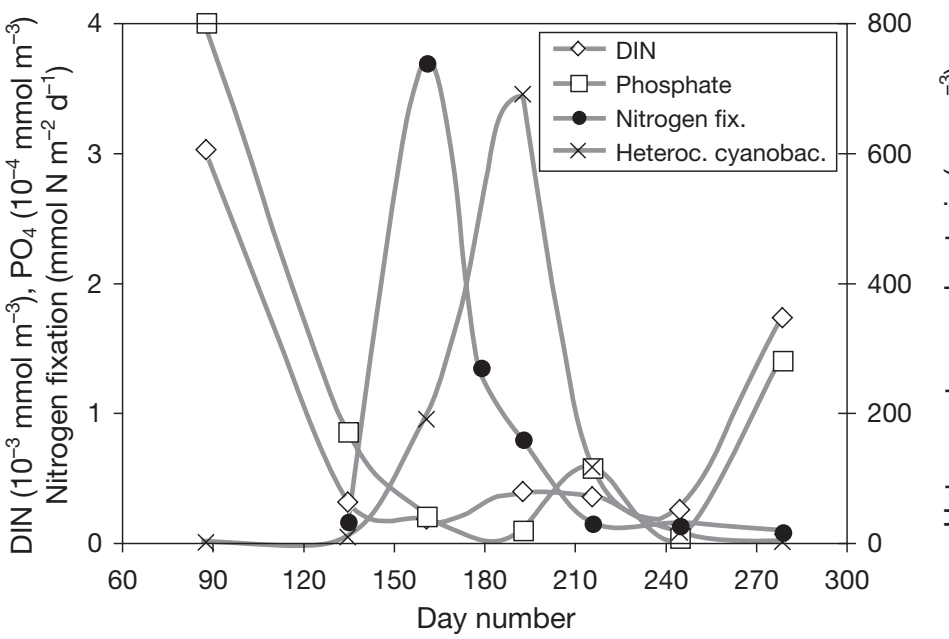

Fig. 2. Annual course of concentrations of $\mathrm{DIN}, \mathrm{PO}_{4}$ and biomass (wet weight) of heterocystous cyanobacteria in the upper mixed layer as well as nitrogen fixation rates in the euphotic zone at Stn BMP J1 in 2001

Complete $\mathrm{PO}_{4}$ depletion was confined to the upper $25 \mathrm{~m}$ and occurred after the stabilisation of the thermocline. The total $\mathrm{PO}_{4}$ loss during March to August, including the slight contribution by atmospheric deposition (0.5 $\mu \mathrm{mol} \mathrm{m} \mathrm{m}^{-2} \mathrm{~d}^{-1}$, Wulff et al. 2001), was $21.5 \mathrm{mmol} \mathrm{m}^{-2}$. Using the standard PON/ POP ratio (16), this corresponds to a nitrogen demand of $344 \mathrm{mmol} \mathrm{m} \mathrm{m}^{-2}$.

DIN concentrations reached a steady state at about $0.5 \mathrm{mmol} \mathrm{m}^{-3}$ (Fig. 3b) already in May, resulting in a loss of $193 \mathrm{mmol} \mathrm{m}^{-2}$ for the period March to August. Taking into account the atmospheric deposition of DIN (0.1 mmol m $\mathrm{m}^{-2} \mathrm{~d}^{-1}$, Herata et al. 2002), the total consumed DIN was $208 \mathrm{mmol} \mathrm{m}^{-2}$ for the period March to August (Table 4). Since $344 \mathrm{mmol} \mathrm{m} \mathrm{m}^{-2}$ are required for the $\mathrm{PO}_{4}$ balance, the difference of $136 \mathrm{mmol} \mathrm{m} \mathrm{m}^{-2}$ may be attributed to nitrogen fixation. This value is

$\mathrm{PO}_{4}$. The total nitrogen fixation can be calculated from the excess $\mathrm{PO}_{4}$ by assuming an invariable PON/POP ratio (16) in the produced organic matter according to:

$$
\text { Nitrogen fixation }=\Delta \mathrm{PO}_{4} \times 16-\Delta \mathrm{DIN}
$$

$\Delta \mathrm{PO}_{4}$ and $\triangle \mathrm{DIN}$ are the concentration changes that refer to the time interval between 2 measurement campaigns. To calculate the changes in $\mathrm{PO}_{4}, 3 \operatorname{rd}(2 \mathrm{nd})$ order polynomials were fitted to the measured $\mathrm{PO}_{4}$ concentrations at Stn BMP J1 (Fig. 3a) and integrated over depth. Considering the entire period March to August, the $\mathrm{PO}_{4}$ depletion extended to a depth of about $60 \mathrm{~m}$ and exceeded considerably the depth of the euphotic zone. This is attributed to the low stability of the spring thermocline, which is intermittently eroded by deeper mixing. As a consequence, nutrient consumption is also observed below the euphotic zone. consistent with the integrated nitrogen fixation rate measurements. However, a substantially higher nitrogen fixation rate was calculated when PON/POP ratios measured in the particulate organic matter (POM) during the cruises were used. The ratios (Table 1) were higher than the classical Redfield ratio and consequently increased the nitrogen requirement (223 mmol m${ }^{-2}$ ) in order to meet the $\mathrm{PO}_{4}$ balance.

Serious discrepancies between the rate measurements and the nutrient concept are revealed if the nitrogen balances are calculated separately for the individual time intervals between the measurements (Table 4). During March to May, the integrated (0 to $60 \mathrm{~m}) \mathrm{PO}_{4}$ decrease was $19.8 \mathrm{mmol} \mathrm{m}^{-2}$ and corresponds to a DIN consumption of $317 \mathrm{mmol} \mathrm{m}^{-2}$ if $\mathrm{PON} / \mathrm{POP}=16$. However, the DIN loss including the contribution by atmospheric deposition amounted to only $195 \mathrm{mmol} \mathrm{m}^{-2}$ and indicates a nitrogen deficit

Table 4. Changes in nutrient concentration $\left(\Delta \mathrm{PO}_{4}, \Delta \mathrm{DIN}\right.$; including atmospheric deposition) and nitrogen fixation calculated from the nutrient concept (with Redfield and measured PON/POP ratios), $\mathrm{CO}_{2}$ concept and biomass concept in comparison with measured nitrogen fixation rates for the periods between the cruises in 2001; all data from Stn BMP J1 in the upper $60 \mathrm{~m}$ $\left(\mathrm{CO}_{2}\right.$ concept only upper mixed layer, according to Schneider et al. 2003). Bold data are the spring values and summer means

\begin{tabular}{|c|c|c|c|c|c|c|c|c|}
\hline $\begin{array}{l}\text { Period } \\
(2001)\end{array}$ & $\begin{array}{l}\text { Duration } \\
\text { (d) }\end{array}$ & $\frac{\Delta \mathrm{PO}_{4}{ }^{3-}}{\left(\mathrm{mmol} \mathrm{m}^{-2}\right)}$ & $\begin{array}{c}\Delta \mathrm{DIN} \\
\left(\mathrm{mmol} \mathrm{m}^{-2}\right)\end{array}$ & $\begin{array}{c}\text { N deficit } \\
\text { (with Redfield } \\
\text { PON/POP) } \\
\text { (mmol N m}{ }^{-2} \text { ) } \\
\text { 'nutrient } \\
\text { concept' }\end{array}$ & $\begin{array}{c}\mathrm{N} \text { deficit } \\
\text { (with measured } \\
\text { PON/POP) } \\
\left(\mathrm{mmol} \mathrm{N} \mathrm{m}^{-2} \text { ) }\right. \\
\text { 'nutrient } \\
\text { concept' }\end{array}$ & $\begin{array}{c}\text { N deficit } \\
(\mathrm{POC} / \mathrm{PON}) \\
\left(\mathrm{mmol} \mathrm{N} \mathrm{m}^{-2}\right) \\
{ }^{\circ} \mathrm{CO}_{2} \text { concept' }\end{array}$ & $\begin{array}{c}\mathrm{TN} \text { increase + } \\
\text { sedimentation } \\
\left(\mathrm{mmol} \mathrm{N} \mathrm{m}^{-2}\right) \\
\text { 'biomass } \\
\text { concept' }\end{array}$ & $\begin{array}{c}\text { measured } \\
\text { nitrogen } \\
\text { fixation rate } \\
\left(\mathrm{mmol} \mathrm{N} \mathrm{m}{ }^{-2}\right.\end{array}$ \\
\hline $28.3-13.5$ & 47 & -19.8 & -195 & $122(16)$ & $201(20)$ & $108(8.1)$ & $64-91$ & 1 \\
\hline $14.5-11.6$ & 29 & -1.5 & -8 & $16(16)$ & $22(27)$ & 48 (8.9) & $31-49$ & 56 \\
\hline $12.6-13.7$ & 32 & -0.2 & -1 & 2 (16) & $4(34)$ & $106(7.8)$ & $70-88$ & 72 \\
\hline $14.7-3.8$ & 21 & 0.0 & -4 & $-4(16)$ & $-4(33)$ & $37(7.4)$ & $33-45$ & 10 \\
\hline $14.5-3.8$ & 82 & -1.7 & -13 & 14 & 22 & 191 & $134-182$ & 138 \\
\hline
\end{tabular}




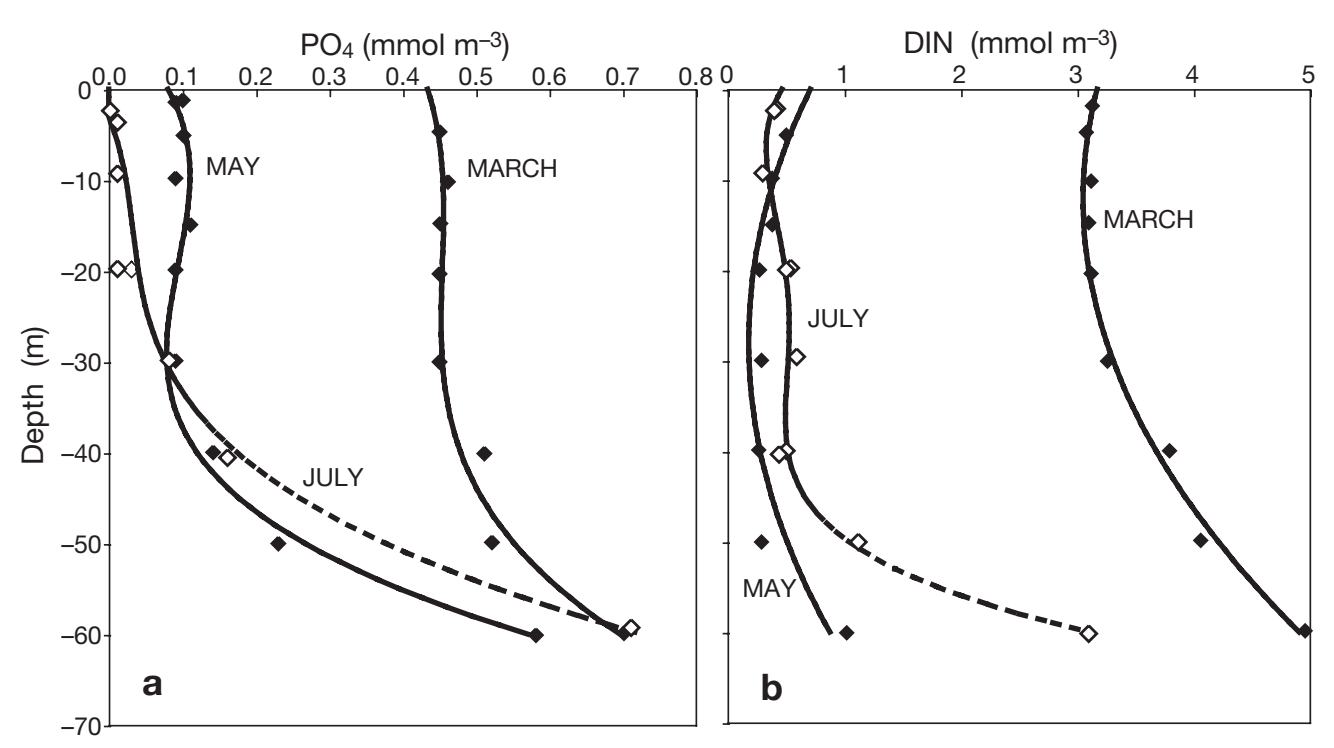

Fig. 3. Depth profiles of (a) $\mathrm{PO}_{4}$ and (b) DIN at Stn BMP J1 in March, May and July 2001

of $122 \mathrm{mmol} \mathrm{m} \mathrm{m}^{-2}$ (Table 4). This deficit is increased to $201 \mathrm{mmol} \mathrm{m}^{-2}$ if the mean PON/POP ratio of 20 from the March and May cruises is used. Since most of the winter $\mathrm{PO}_{4}$ excess was already consumed during March to May, the $\mathrm{PO}_{4}$ depletion that occurred in the upper $25 \mathrm{~m}$ during May to August was only $1.7 \mathrm{mmol} \mathrm{m} \mathrm{m}^{-2}$. Considering the concurrent DIN consumption which was supplied mainly by atmospheric deposition, a nitrogen deficit of $14 \mathrm{mmol} \mathrm{m}^{-2}$ and $22 \mathrm{mmol} \mathrm{m}^{-2}$ was obtained based on the use of the conventional and the measured PON/POP ratios respectively (Table 4). This deficit was certainly compensated for by nitrogen fixation. However, the integrated nitrogen fixation measurements for this time span revealed a nitrogen fixation of $138 \mathrm{mmol}$ $\mathrm{m}^{-2}$. Hence, the nutrient concept yields a seasonal nitrogen fixation pattern in contrast to the results of the rate measurements.

\section{$\mathrm{CO}_{2}$ concept}

Schneider et al. (2003) used $\mathrm{CO}_{2}$ partial pressure measurements which were performed during each of the cruises between March and September 2001 to establish a carbon balance for the upper mixed layer in the eastern Gotland Sea. Taking into account the $\mathrm{CO}_{2}$ air/sea exchange, deepening of the upper mixed layer in late summer and seasonal changes of the DOC concentrations, the authors calculated the net community production for each monthly time interval. Using measured POC/PON ratios (Table 4), the nitrogen demand was calculated and used to establish a nitrogen budget which accounted for changes in DIN and DON concen- trations and for the atmospheric DIN deposition. The imbalance (deficit) in the budget was attributed to nitrogen supply by nitrogen fixation and amounted to $299 \mathrm{mmol} \mathrm{m}^{-2}$ for the period March to August with contributions of $108 \mathrm{mmol} \mathrm{m}^{-2}$ and $191 \mathrm{mmol} \mathrm{m}^{-2}$ from March to May and May to August respectively. Hence, the nitrogen fixation rate calculated for the entire period, and in particular for March to May, exceeded the results of the rate measurements substantially.

\section{Biomass concept}

The increase in total nitrogen $(\mathrm{TN}=\mathrm{DIN}+\mathrm{PON}+$ DON, $N_{2}$ excluded) in the euphotic zone during the productive period, including the fraction removed by sedimentation, is assumed to be caused by nitrogen fixation. Larsson et al. (2001) applied this approach to data from the western Gotland Sea by calculating the difference of the $\mathrm{TN}$ concentrations $(\Delta \mathrm{TN})$ in the upper $20 \mathrm{~m}$ and those below the thermocline (25 to $30 \mathrm{~m}$ ). By using the difference between the 2 water layers, $\Delta \mathrm{TN}$, a possible bias by sampling water masses with a different nutrient background was avoided. The increase in $\triangle \mathrm{TN}$ from one sampling to the next was attributed to nitrogen fixation. We applied this method to our monthly measurements by subtracting the TN at a depth of about $30 \mathrm{~m}$ from the $\mathrm{TN}$ in the euphotic zone. The contribution of atmospheric nitrogen deposition of $0.1 \mathrm{mmol} \mathrm{m}^{-2} \mathrm{~d}^{-1}$ (Herata et al. 2002) was subtracted, whereas a sedimentation rate of 24 to $42 \mathrm{mmol}$ $\mathrm{N} \mathrm{m}^{-2} \mathrm{mo}^{-1}$ (Larsson et al. 2001) was added in order to determine the $\Delta \mathrm{TN}$ increase assigned to nitrogen fixation (Table 4). 
The total $\triangle \mathrm{TN}$ increase ranged between $198 \mathrm{mmol}$ $\mathrm{m}^{-2}$ and $273 \mathrm{mmol} \mathrm{m}^{-2}$. This includes a peak (64 to $91 \mathrm{mmol} \mathrm{m}^{-2}$ ) during March to May that cannot be attributed to nitrogen fixation. Larsson et al. (2001) also found this nutrient input and explained it by enhanced river water input during spring. Accepting this explanation also for the eastern Gotland Sea gives a reduced annual nitrogen fixation of 134 to $182 \mathrm{mmol} \mathrm{m}^{-2}$.

\section{DISCUSSION}

\section{Comparison of the different concepts for the period from March to May}

Direct observations and measurements (Hübel \& Hübel 1995, Wasmund et al. 2001b) have indicated that cyanobacteria blooms and nitrogen fixation in the Baltic Sea are insignificant during the period from March to May. In contrast, our budget approaches suggest a considerable nitrogen fixation for this period. The nitrogen deficit calculated for March to May (Table 4) from the nutrient concept was based on the observation that more $\mathrm{PO}_{4}$ was available than needed for a balanced (PON/POP = 16) and DIN-limited primary production. As this excess $\mathrm{PO}_{4}$ was also consumed, presumably in primary production, an additional nitrogen source should exist to replenish the deficit. Rahm et al. (2000) concluded this source was nitrogen fixation. The discrepancy between spring $\mathrm{PO}_{4}$ consumption and summer nitrogen fixation requires phosphorus transfer, probably by storage. Storage of phosphorus by nitrogen-fixing cyanobacteria was reported by Huber \& Hamel (1985) and Thompson et al. (1994). This is consistent with studies by Larsson et al. (2001), who found low POC/POP ratios in spring POM, indicating internal storage of phosphorus. However, our measurements showed no lowering of the POC/POP ratios, and we therefore question the storage hypothesis. Since no changes were observed in DOP concentrations either, the excess $\mathrm{PO}_{4}(7.6 \mathrm{mmol}$ $\mathrm{m}^{-2}$ ) must have been used for the production of organic matter (POP), which implies the input of additional nitrogen. Using the classical Redfield POC/PON ratio (16) the required nitrogen input amounts to $122 \mathrm{mmol}$ $\mathrm{m}^{-2}$, whereas a value of $201 \mathrm{mmol} \mathrm{m}^{-2}$ is obtained on the basis of the mean measured POC/PON ratio (20) in March and May.

For the March to May time span, the $\mathrm{CO}_{2}$ approach and the biomass concept also yielded additional nitrogen demands of $108 \mathrm{mmol} \mathrm{m}^{-2}$ (for the upper $15 \mathrm{~m}$ only) and of 64 to $91 \mathrm{mmol} \mathrm{m}^{-2}$ respectively (Table 4 ). However, we hesitate to attribute these values to nitrogen fixation because nitrogen-fixing cyanobacteria were scarce at that time (Fig. 2) and no other indica- tions exist for such an early nitrogen fixation. Nitrogen fixation should decrease the POC/PON ratio, but instead slightly increased values were observed for the period from March to May. A potential alternative internal nitrogen source is DON (Berg et al. 2003, Berman \& Bronk 2003, Glibert et al. 2004). But the slight reduction in the DON concentrations cannot replenish the large nitrogen deficit during this period. As a consequence, an external nitrogen source must exist which, however, could not be identified on the basis of our data.

\section{Comparison of the different concepts for the period from May to August}

The integrated measured nitrogen fixation rates amounted to $138 \mathrm{mmol} \mathrm{N} \mathrm{m}^{-2}$ for the period from May to August. This magnitude is consistent with earlier studies (e.g. Wasmund et al. 2001b). The nitrogen fixation rates derived from the nutrient concept were extremely low for the summer period (Table 1) because $\mathrm{PO}_{4}$ was widely exhausted already in May. If the spring excess $\mathrm{PO}_{4}$ was not stored in the system, the nitrogen-fixing cyanobacteria must have exploited another phosphorus source. Since the PON/POP ratios increased drastically from May (18.7) to July (35.4), selective release of $\mathrm{PO}_{4}$ from the POP pool present in May may have provided some of the phosphorus. This was confirmed by Nausch et al. (2004), who found that the development of plankton biomass was based on the intracellular phosphorus pool in July 2001. However, a rough estimate shows that a further source is necessary to close the phosphorus budget. Kononen et al. (1996) realised that the cyanobacteria bloom was initiated by an upwelling event that may have introduced new phosphorus into the system. But phosphorus inputs of the required magnitude by upwelling are unlikely in the deep central sea areas. Also, the nutrient exchange with the Bothnian Sea is low (Wulff et al. 2001). Advection from shallower coastal areas where the water interacts with the sediment surface and picks up $\mathrm{PO}_{4}$ is a possible source, however, whereas nutrient inputs by rivers do not reach the Gotland Sea in summer because they are rapidly consumed and diluted in the coastal waters (Humborg et al. 1998, Wasmund et al. 2001a).

The decoupling between spring and summer phosphorus systems, i.e. the incomplete transfer of spring $\mathrm{PO}_{4}$ to summer populations, implies that the nutrient concept is not applicable. The unrealistic low nitrogen fixation rates for the period May to August (Table 4) would become even lower if the decrease in the DON concentrations during May to June were included in the budget calculations. 
The biomass concept is based on direct measurements of DIN, PON and DON without the need for conversions using elemental ratios. Taking into account the uncertainties involved in each of the approaches, the estimated nitrogen fixation rate of 134 to $182 \mathrm{mmol} \mathrm{N} \mathrm{m}^{-2}$ agrees reasonably with the integrated rate measurements. The nitrogen fixation estimate based on the $\mathrm{CO}_{2}$ concept was confined to the mixed layer and amounted to $191 \pm 50 \mathrm{mmol} \mathrm{N} \mathrm{m}{ }^{-2}$. This value will increase by about $40 \%$ if extended to the euphotic zone, assuming the same nitrogen fixation ratio between upper mixed layer and euphotic zone as in the rate measurements. Using this factor, a nitrogen fixation of $268 \mathrm{mmol} \mathrm{N} \mathrm{m}^{-2}$ could be calculated for the euphotic zone from the $\mathrm{CO}_{2}$ concept. We consider this estimate as an upper limit for nitrogen fixation because the $\mathrm{CO}_{2}$ approach does not explicitly determine nitrogen fixation but assigns the closing term in a mass balance to nitrogen fixation. Hence any unknown nitrogen input term will lead to an overestimation of nitrogen fixation. However, samplings for nitrogen fixation rate measurements may miss the maximum of nitrogen fixation activity. Therefore, field measurements tend to an underestimation, and the value of $138 \mathrm{mmol} \mathrm{N} \mathrm{m}^{-2}$ represents a lower limit.

\section{Budget of nitrogen fixation}

Since rate measurements did not show any evidence for early nitrogen fixation (March to May), the input of nitrogen resulting from the mass balance approaches in spring were not interpreted as nitrogen fixation. The high spring values of the nutrient concept would be applicable for estimations of nitrogen fixation if phosphorus transfer to the summer bloom were proved. The 3 different concepts were applied only for the main period of nitrogen fixation, lasting until the beginning of August. The results can roughly be considered as annual nitrogen fixation data. Rate measurements continued until 6 October 2001, at which time they still revealed some nitrogen fixation $\left(9 \mathrm{mmol} \mathrm{N} \mathrm{m}^{-2}\right.$ ) after the cyanobacteria bloom. Adding this contribution led to an annual nitrogen fixation rate of $148 \mathrm{mmol} \mathrm{N} \mathrm{m}^{-2}$. This estimate is higher than the mean nitrogen fixation rates from 1997 and 1998 measured in the same region by Wasmund et al. (2001b). Their value of $125 \mathrm{mmol} \mathrm{N}$ $\mathrm{m}^{-2} \mathrm{a}^{-1}$ might be an underestimate because they missed the early stages of the bloom in June and early July. Ohlendieck et al. (2000) noticed that these early stages are especially active in nitrogen fixation. We can confirm this, since our highest nitrogen fixation was found on 10 June 2001 while the cyanobacteria biomass peak occurred on 13 July 2001 (Fig. 2). Nitrogen fixation rates by Larsson et al. (2001) ranged from
61 to $140 \mathrm{mmol} \mathrm{N} \mathrm{m}^{-2} \mathrm{a}^{-1}$ in the years 1994 to 1998 . Applying the nutrient concept, Rahm et al. (2000) estimated a nitrogen fixation rate of 14.3 to $214 \mathrm{mmol} \mathrm{N}$ $\mathrm{m}^{-2} \mathrm{a}^{-1}$ in the Baltic Proper. Hübel \& Hübel (1995) measured annual nitrogen fixation rates in the Gotland Sea between 3.4 and $37.1 \mathrm{mmol} \mathrm{N} \mathrm{m}^{-2}$. They found a maximum of $320 \mathrm{mmol} \mathrm{N} \mathrm{m}^{-2}$ in 1975 in the Arkona Sea. Most other early investigations, compiled by Wasmund et al. (2001b), underestimated nitrogen fixation substantially because of methodological drawbacks like loss of the small-sized fraction due to net sampling.

The advantage of our nutrient, biomass and $\mathrm{CO}_{2}$ concepts is that they are based mainly on measurements of dissolved constituents, which are less susceptible to patchiness than particulate matter. Schneider et al. (2003) found a fairly even distribution of different dissolved substances in a station grid in the eastern Gotland Sea. Also, rate measurements in different areas of the Baltic Proper (Wasmund et al. 2001b) showed a widely homogenous distribution of the nitrogen fixation activity. Therefore, we considered the central station in the eastern Gotland Sea to be representative of the Baltic Proper and extrapolated our nitrogen fixation rates to the area of the entire Baltic Proper.

Since we included pico- and nanoplankton and the total vegetation period in our investigations, our estimate of nitrogen fixation in the entire Baltic Proper is higher than that based on previous data. From our rate measurements we calculated an annual nitrogen fixation of $434000 \mathrm{t} \mathrm{N}$, which is 4 times higher than earlier estimates (Melvasalo et al. 1983, Rönner 1985, Leppänen et al. 1988). This is not far from estimates by Wasmund et al. (2001b) and Larsson et al. (2001). It is higher than the entire riverine load (363000 t N yr-1) and more than twice the atmospheric load (185000 $\mathrm{t} \mathrm{N}$ $\mathrm{yr}^{-1}$ ) to the Baltic Proper (load data compiled by Elmgren \& Larsson 2001). Compared with the integrating concepts of estimation, the rate measurements (434000 t N) mark the lower limit of a reliable range, whereas the upper limit results from the $\mathrm{CO}_{2}$ concept (792000 t N). The Baltic Proper is the marine region with the most intensive nitrogen fixation per area. It covers only $0.06 \%$ of the area of the world ocean but accounts for 0.3 to $0.6 \%$ of the global oceanic nitrogen fixation, which is $135 \times 10^{6} \mathrm{t} \mathrm{N} \mathrm{yr}^{-1}$ according to Gruber (2004).

Acknowledgements. We thank the crews of RV 'Alexander v. Humboldt' and RV 'Professor Albrecht Penck' for their support during the cruises. We are also grateful to our colleagues B. Buuk, R. Hansen and I. Topp for assistance in experimental work during the cruises and K. Bohn, S. Busch, A. Grüttmüller, I. Liskow, B. Sadkowiak and A.-M. Welz for analytical work in the lab. The valuable hints and fruitful discussions with M. Nausch are appreciated. 


\section{LITERATURE CITED}

Berg GM, Balode $\mathrm{M}$, Purina I, Bekere S, Béchemin C, Maestrini SY (2003) Plankton community composition in relation to availability and uptake of oxidized and reduced nitrogen. Aquat Microb Ecol 30:263-274

Bergström S, Carlsson B (1994) River runoff to the Baltic Sea - 1950-1990. Ambio 23:280-287

Berman T, Bronk DA (2003) Dissolved organic nitrogen: a dynamic participant in aquatic ecosystems. Aquat Microb Ecol 31:279-305

Cauwet G (1999) Determination of dissolved organic carbon and nitrogen by high temperature combustion. In: Grasshoff K, Kremling K, Ehrhardt M (eds) Methods of seawater analysis. Wiley-VCH, Weinheim, p 408-420

Ehrhardt M, Koeve W (1999) Determination of particulate organic carbon and nitrogen. In: Grasshoff K, Kremling K, Ehrhardt $M$ (eds) Methods of seawater analysis. Wiley$\mathrm{VCH}$, Weinheim, p 437-444

Elmgren R, Larsson U (2001) Eutrophication in the Baltic Sea area: integrated coastal management issues. In: v Bodungen B, Turner R (eds) Science and integrated coastal management. Dahlem University, Berlin, p 15-35

Glibert PM, Heil CA, Hollander D, Revilla M, Hoare A, Alexander J, Murasko S (2004) Evidence for dissolved organic nitrogen and phosphorus uptake during a cyanobacterial bloom in Florida Bay. Mar Ecol Prog Ser 280:73-83

Grasshoff K, Ehrhardt M, Kremling K (1983) Methods of seawater analysis. Chapter 4. Determination of nutrients. Verlag Chemie, Weinheim

Gruber N (2004) The dynamics of the marine nitrogen cycle and its influence on atmospheric $\mathrm{CO}_{2}$ variations. In: Follows M, Oguz T (eds) Carbon-climate interactions. Kluwer Academic, Dordrecht, p 97-148

HELCOM (1988) Guidelines for the Baltic Monitoring Programme for the third stage. Part D. Biological determinands. Balt Sea Environ Proc 27 D:1-161

Herata H, Svendsen LM, Ruoho-Airola T, Brusendorff AC (2002) Inputs to the Baltic marine environment. Balt Sea Environ Proc 82B:29-38

Hübel H, Hübel M (1995) Blaualgen-Wasserblüten in der Ostsee: Ursachen-Ausmaß-Folgen. Dtsch Hydrogr Z Suppl 2: 151-158

Huber AL, Hamel KS (1985) Phosphatase activities in relation to phosphorus nutrition in Nodularia spumigena (Cyanobacteriacea). 2. Laboratory studies. Hydrobiologia 123: 81-88

Humborg C, Nausch G, Neumann T, Pollehne F, Wasmund N (1998) The exceptional Oder flood in summer 1997 - the fate of nutrients and particulate organic matter in the Baltic Sea. Dtsch Hydrogr Z 50:169-181

Jeffrey SW, Welschmeyer NA (1997) Spectrophotometric and fluorometric equations in common use in oceanography. In: Jeffrey SW, Mantoura RFC, Wright SW (eds) Phytoplankton pigments in oceanography: guidelines to modern method. UNESCO Publishing, Paris, p 597-615

Kahru M, Horstmann U, Rud O (1994) Satellite detection of increased cyanobacteria blooms in the Baltic Sea: natural fluctuations or ecosystem change? Ambio 23:469-472

Kononen K, Kuparinen J, Mäkelä K, Laanemets J, Pavelson J, Nõmmann S (1996) Initiation of cyanobacterial blooms in a frontal region at the entrance to the Gulf of Finland, Baltic Sea. Limnol Oceanogr 41:98-112

Larsson U, Hajdu S, Walve J, Elmgren R (2001) Baltic Sea nitrogen fixation estimated from the summer increase in upper mixed layer total nitrogen. Limnol Oceanogr 46:811-820
Leppänen JM, Niemi $\AA$, Rinne I (1988) Nitrogen fixation of Cyanobacteria (Blue-green algae) and the nitrogen cycle of the Baltic Sea. Symbiosis 6:181-194

Matthäus W, Nausch G, Lass HU, Nagel K, Siegel H (2001) Hydrographisch-chemische Zustandseinschätzung der Ostsee 2000. Meereswiss Ber Warnemünde 45:27-88

Melvasalo T, Niemi, $\AA$, Niemistö L, Rinne I (1983) On the importance of the nitrogen fixation in the Baltic Sea ecosystem. In: Symposium on Ecological Investigations of the Baltic Sea Environment, Riga, Latvia, 16-19 March 1983, p 176-189

Montoya JP, Voss M, Kähler P, Capone DG (1996) A simple, high-precision, high-sensitivity tracer assay for $\mathrm{N}_{2}$ fixation. Appl Environ Microbiol 62:986-993

Nausch G, Feistel R, Lass HU, Nagel K, Siegel H (2002) Hydrographisch-chemische Zustandseinschätzung der Ostsee 2001. Meereswiss Ber Warnemünde 49:1-77

Nausch M, Nausch G, Wasmund N (2004) Phosphorus dynamics during the transition from nitrogen to phosphate limitation in the central Baltic Sea. Mar Ecol Prog Ser 266: $15-25$

Ohlendieck U, Stuhr A, Siegmund H (2000) Nitrogen fixation by diazotrophic cyanobacteria in the Baltic and transfer of the newly fixed nitrogen for picoplankton organisms. J Mar Syst 25:213-219

Rahm L, Jönsson A, Wulff F (2000) Nitrogen fixation in the Baltic Proper: an empirical study. J Mar Syst 25:239-248

Redfield AC, Ketchum BH, Richards FA (1963) The influence of organisms on the composition of seawater. In: Hill MN (ed) The sea, Vol 2. John Wiley, New York, p 26-77

Rohde KH, Nehring D (1979) Ausgewählte Methoden zur Bestimmung von Inhaltsstoffen im Meer- und Brackwasser. Geod Geophys Veroeff, Reihe IV, 27:1-68

Rönner U (1985) Nitrogen transformations in the Baltic proper: denitrification counteracts eutrophication. Ambio 14:134-138

Schneider B, Nausch G, Nagel K, Wasmund N (2003) The surface water $\mathrm{CO}_{2}$ budget for the Baltic Proper: a new way to determine nitrogen fixation. J Mar Syst 42:53-64

Sellner KG (1997) Physiology, ecology and toxic properties of marine cyanobacteria blooms. Limnol Oceanogr 42: 1089-1104

Sharp JH (2002) Analytical methods for total DOM pools. In: Hansell DA, Carlson CA (eds) Biogeochemistry of marine dissolved organic matter. Academic Press, San Diego, CA, p 35-58

Thompson PA, Oh HM, Rhee GY (1994) Storage of phosphorus in nitrogen-fixing Anabaena flos-aquae (Cyanophyceae). J Phycol 30:267-273

Wasmund N, Nausch G, Matthäus W (1998) Phytoplankton spring blooms in the southern Baltic Sea-spatiotemporal development and long-term trends. J Plankton Res 20:1099-1117

Wasmund N, Andrushaitis A, Łysiak-Pastuszak E, MüllerKarulis B and 6 others (2001a) Trophic status of the southeastern Baltic Sea: a comparison of coastal and open areas. Estuar Coast Shelf Sci 53:849-864

Wasmund N, Voss M, Lochte K (2001b) Evidence of nitrogen fixation by non-heterocystous cyanobacteria in the Baltic Sea and re-calculation of a budget of nitrogen fixation. Mar Ecol Prog Ser 214:1-14

Wulff F, Rahm L, Hallin AK, Sandberg J (2001) A nutrient budget model of the Baltic Sea. In Wulff $F$, Rahm L, Larsson P (eds) A system analysis of the Baltic Sea. Springer Verlag, Berlin, p 353-372

Submitted: November 29, 2004; Accepted: March 22, 2005

Proofs received from author(s): July 4, 2005 